\title{
Monitoring Proses Pengolahan Makanan Moslem Meal Di PT. Aerofood Indonesia, Tangerang, Banten
}

\section{Monitoring of Moslem Meal Preparation Process in PT Aerofood Indonesia Tangerang, Banten}

\author{
Anisa Nindyasari*1, ${ }^{*}$ rias Mahmudiono ${ }^{1}$, Sri Sumarmi ${ }^{1}$
}

\begin{abstract}
ABSTRAK
Latar Belakang: PT. Aerofood Indonesia adalah perusahaan layanan katering penerbangan bertaraf internasional. Jenis makanan yang dibuat seperti Asian cuisine, Japanese/Korean cuisine, Western cuisine, pastry and bakery, dan lain-lain untuk para penumpang pesawat. PT. Aerofood Indonesia membuktikan perhatiannya kepada customer yang memiliki kebutuhan khusus dengan mengadakan menu special meal, salah satunya adalah menu khusus untuk muslim, yaitu Moslem Meal (MOML). Untuk memproduksi menu MOML, membutuhkan proses yang dimulai dari penerimaan bahan, penyimpanan, persiapan, pengolahan, portioning, pengemasan sampai dengan distribusi. Dalam setiap tahapan pengolahan makanan diperlukan monitoring kualitas pangan untuk menjaga kualitas produk makanan dan minuman. Kualitas makanan yang baik akan terhindar dari bahaya kontaminasi makanan baik secara fisik, kimia, dan biologi sehingga tidak menimbulkan gangguan kesehatan.

Tujuan: Tujuan dari penelitian ini adalah untuk mengetahui proses produksi penyelenggaraan makanan di inflight catering, khususnya pada produk special meal (moslem meal) dari penerimaan bahan, penyimpanan, persiapan, pengolahan, portioning, pengemasan hingga pendistribusian makanan ke dalam pesawat di PT. Aerofood Indonesia.

Metode: Metode yang digunakan adalah deskriptif dengan pendekatan kualitatif.

Hasil: Hasil penelitian meliputi monitoring pada menu moslem meal dilakukan dari penerimaan bahan baku, penyimpanan, persiapan, pengolahan produk, portioning, meal tray set up hingga pendistribusian ke dalam pesawat. Dalam proses pengolahannya, produk halal dengan produk non halal dipisahkan tempat dan equipmentnya dari area hot kitchen hingga di-dishing. Monitoring disetiap area produksi difokuskan pada critical control point yang telah ditetapkan oleh PT. Aerofood Indonesia.

Kesimpulan: Monitoring pada menu moslem meal dilakukan dari penerimaan bahan baku, penyimpanan bahan baku, persiapan bahan baku, pengolahan produk, portioning, meal tray set up hingga pendistribusian ke dalam pesawat.
\end{abstract}

Kata kunci: monitoring, pengolahan makanan, katering pesawat 


\section{ABSTRACT}

Background: PT. Aerofood Indonesia is an international flight catering company that specializes in Asian, Japanese, Korean, and Western cuisines, as well as pastry and bakery for airline passengers. PT. Aerofood Indonesia also offers special service to its diverse customers by providing special menu, such as moslem meal (MOML). To create MOML menu, there are several procedures that need to be fulfilled, i.e. ingredient and product delivery, storage, preparation production, portioning, packaging, and distribution. Food quality control is needed in each of the procedure to maintain the quality of the beverages. Good quality beverage will prevent physical, chemical, and biological contamination, thus averting the risk of customer health issues.

Objectives: This study aimed to gain in-depth knowledge about food production process in in-flight catering, especially in special meal/moslem meal product from delivery, storage, preparation production, portioning, packaging, until the final distribution process to customer inside the airplane.

Methods: This study used descriptive method with qualitative approach to achieve the objective.

Results: The results showed that quality monitoring for MOML was applied for basic ingredients delivery, storage, preparation, production, portioning, meal tray setup and meal distribution into the airplane. Halal and non halal ingredients were separated by containers and equipments from hot kitchen through portioning area. Monitoring process in each of the production step was focused on critical control point established by PT. Aerofoof Indonesia.

Conclusion: Monitoring on moslem meal have been done from food acceptance, storage, through cooking, processing, portioning, meal tray set up and distribution inside the plane.

Keywords: monitoring, food preparation, inflight catering

\footnotetext{
*Koresponden:

nindyasari03@yahoo.co.id

${ }^{1}$ Departemen Gizi Kesehatan, Fakultas

Kesehatan Masyarakat-Universitas Airlangga
}

\section{PENDAHULUAN}

Makanan merupakan salah satu kebutuhan utama dan paling mendasar bagi manusia. Semakin maju suatu bangsa, tuntutan dan perhatian terhadap kualitas makanan semakin besar ${ }^{1}$. Industri pelayanan makanan memiliki tujuan untuk menyediakan makanan yang berkualitas dan aman untuk dikonsumsi. Kualitas layanan yang baik dapat menciptakan pembelian berulang dan loyalitas pelanggan ${ }^{2}$. Salah satu kebutuhan makanan saat ini yang semakin meningkat adalah kebutuhan makanan pada katering penerbangan. Karena kebutuhan yang terus meningkat, maka perusahan katering penerbangan dituntut untuk dapat menghasilkan makanan yang berkualitas dari segi nilai gizi, rasa, serta aman untuk dikonsumsi ${ }^{3}$.
PT. Aerofood Indonesia merupakan penyedia airline catering bertaraf internasional yang telah berjalan selama lebih dari 42 tahun ${ }^{4}$. PT. Aerofood Indonesia berkomitmen untuk memenuhi kebutuhan makanan didalam pesawat dan berperan aktif sebagai penyedia jasa pendukung bagi maskapai Garuda Indonesia sebagai induk perusahaannya dan beberapa foreign airlines. Dalam penyelenggaraannya, PT. Aerofood Indonesia menggunakan bahan-bahan terbaik dari produk pertanian segar untuk meningkatkan kualitas makanan dan memastikan bahwa makanan sehat untuk dikonsumsi ${ }^{5}$.

Perusahaan katering bertaraf internasional ini menyediakan berbagai jenis makanan seperti Asian cuisine, Japanese/Korean cuisine, western cuisine, pastry and bakery, dan lain-lain untuk para penumpang pesawat. PT. Aerofood Indonesia membuktikan perhatiannya kepada customer 
yang memiliki kebutuhan khusus, dengan mengadakan menu special meal seperti VLML (Vegetarian Lacto Ovo Vegetarian), LCML (Low Calorie Meal), DBML (Diabetic Meal), LCML (Low Fat/Low Cholesterol Meal), BBML (Baby Meal), CHML (Children Meal), MOML (Moslem Meal), dan lain-lain ${ }^{5}$. PT. Aerofood Indonesia merupakan jasa layanan catering yang mementingkan kehalalan produk yang dihasilkan, sehingga terdapat menu khusus untuk muslim yaitu Moslem Meal (MOML). Moslem meal merupakan menu yang tidak mengandung produk berbahan baku babi dan alkohol.

Produk makanan yang dihasilkan oleh PT. Aerofood Indonseia telah memiliki sertifikat halal dari MUI sehingga produk tersebut sudah terjamin kehalalannya. PT. Aerofood Indonesia juga menerapkan sistem HACCP, ISO 9001:2008 untuk Manajemen Mutu Pangan dan ISO 22000:2005 untuk Manajemen Keamanan Pangan ${ }^{5}$. HACCP berfungsi untuk mencegah terjadinya bahaya sehingga dapat digunakan sebagai jaminan mutu pangan guna memenuhi kebutuhan konsumen. ISO 22000 merupakan standar system manajemen keamanan pangan untuk seluruh rantai makanan, dari mulai petani hingga penjualan.

Bagi produk makanan, sistem pengendalian mutu diawali dengan penerapan GMP (Good Manufacturing Practice), yakni mendefinisikan dan mendokumentasikan semua persyaratan yang diperlukan agar produk pangan dapat diterima mutunya ${ }^{6}$. Dengan adanya sistem pengendalian mutu ini, diharapkan suatu industri pangan dapat meminimalisir adanya gangguan kesehatan akibat aspek pangan, serta bagi industri sendiri akan menghemat biaya produksi serta dapat bersaing dengan industri pangan lainnya.

Makanan dikatakan halal tidak hanya terhindar dari makanan yang dilarang untuk dikonsumsi, namun kebersihan dalam seluruh proses pengolahan makanan termasuk higiene personal dan kebersihan equipment juga ${ }^{7}$. Sehingga dalam proses produksi makanan di PT. Aerofood Indonesia perlu diadakan pengawasan atau monitoring makanan halal dan kualitas makanan disetiap proses produksinya. Kualitas makanan yang baik akan terhindar dari bahaya kontaminasi makanan baik secara fisik, kimia, dan biologi sehingga tidak menimbulkan gangguan kesehatan. Monitoring proses produksi dilakukan mulai dari penerimaan bahan baku, penyimpanan bahan baku, persiapan bahan baku, proses pengolahan makanan, portioning makanan, pengemasan hingga pendistribusian kedalam pesawat. Dimana dalam alur proses produksinya dari penerimaan bahan hingga pendistribusian produk memiliki risiko.

Kegiatan produksi yang mementingkan kehalalan produk yang dihasilkan menjadi daya tarik bagi penulis untuk melakukan penelitian pada Departemen quality health safety environment. Banyaknya maskapai yang dilayani oleh PT. Aerofood Indonesia baik dalam negeri atau luar negeri membuat bahan baku yang diperlukan tidak hanya berasal dari dalam negeri saja. Oleh karena itu, penulis ingin mendalami proses produksi khususnya produk halal di PT. Aerofood Indonesia.

Tujuan penelitian ini adalah untuk mengidentifikasi proses produksi penyelenggaraan makanan di inflight catering, khususnya pada produk special meal (moslem meal) dari penerimaan bahan baku, penyimpanan bahan baku, persiapan bahan baku, proses pengolahan makanan, portioning makanan, pengemasan hingga pendistribusian makanan ke dalam pesawat di PT. Aerofood Indonesia. Manfaat dari penelitian ini adalah mendapat gambaran mengenai proses produksi penyelenggaraan makanan produk halal di PT. Aerofood Indonesia.

\section{METODE}

Metode penelitian ini menggunakan pendekatan kualitatif dengan metode yang digunakan adalah observasi dan wawancara. Penelitian ini dilakukan di PT. Aerofood Indonesia, Tangerang, Banten dalam waktu kurang lebih satu bulan, dimulai dari bulan Februari hingga Maret 2017. Sampel penelitian ini merupakan makanan pada menu special meal (moslem meal) di PT. Aerofood Indonesia.

Penelitian ini menggunakan instrument berupa instrument penilaian observasi yang disusun oleh PT. Aerofood Indonesia, yaitu 
lembar verifikasi CCP dan form performance area. Observasi langsung dilakukan dengan cara melihat langsung pelaksanaan proses pengolahan makanan khususnya pada produk special meal (moslem meal) di PT. Aerofood Indonesia.

Pelaksanaan observasi didampingi oleh staf dari PT. Aerofood Indonesia yaitu staf Quality Control. Wawancara dilakukan untuk mendapatkan informasi terkait bagaimana proses pengawasan pada produk special meal (moslem meal) serta peraturan atau kebijakan yang diterapkan oleh PT. Aerofood Indonesia dalam menjaga dan menghasilkan produk yang berkualitas. Wawancara dilakukan kepada 8 staf Quality Control secara informal yang berada disetiap area produksi.

\section{HASIL DAN PEMBAHASAN}

PT. Aerofood Indonesia merupakan salah satu inflight catering yang menyediakan kebutuhan makanan dan minuman didalam pesawat. Selain melayani kebutuhan makanan dan minuman, PT. Aerofood Indonesia juga menyediakan perlengkapan penunjang lainnya, seperti perlengkapan logistik. Maskapai yang dilayani oleh PT. Aerofood Indonesia tidak hanya maskapai Garuda Indonesia tetapi PT. Aerofood Indonesia juga melayani pesanan makanan dari beberapa foreign airlines.

Special meal merupakan menu yang dikhususkan untuk penumpang yang memiliki kebutuhan khusus karena masalah kesehatan atau kepercayaan. Untuk penumpang yang memiliki kebutuhan khusus dapat memesan menu special meal sesuai dengan kebutuhan mereka yang biasanya dapat dipesan selama 72 jam sebelum keberangkatan pesawat.
Special meal memiliki berbagai macam jenis menu dan memiliki perbedaan menu special meal pada setiap maskapai. Yang salah satunya adalah moslem meal. Moslem meal merupakan menu yang dikhususkan untuk kaum muslim, dimana didalam menu makanannya tidak mengandung produk berbahan baku babi dan alcohol, serta dalam pengolahannya sesuai dengan syariat islam.

Pada dasarnya bahan baku yang digunakan oleh PT. Aerofood Indonesia tidak menggunakan bahan baku yang mengandung babi. Namun terdapat bahan baku yang digunakan untuk mengolah makanan di Japanese dan Korean dishes untuk maskapai penerbangan ke Jepang dan Korea bahan bakunya di impor dari Jepang dan Korea, sehingga PT. Aerofood Indonesia mengatakan bahan baku tersebut adalah syubhat, karena PT. Aerofood Indonesia tidak bisa menjamin kehalalan produk yang diimpor tersebut.

Menurut salah satu staf QHSE PT. Aerofood Indonesia menggunakan bahan baku halal, tetapi khusus untuk maskapai Jepang dan Korea bahan baku impor, sehingga tidak bisa dijamin bahan baku tersebut halal atau tidak (personal communication, 21 Februari 2017).

Untuk menjaga kualitas produk makanan dan minuman, maka diperlukan monitoring kualitas pangan disetiap proses produksinya. Kualitas makanan yang baik akan terhindar dari bahaya kontaminasi makanan baik secara fisik, kimia, dan biologi sehingga tidak menimbulkan gangguan kesehatan. Di setiap komponen pada makanan memiliki batas kritis. PT. Aerofood Indonesia menetapkan 5 critical control point (CCP) pada pengolahan makanan ${ }^{8}$.

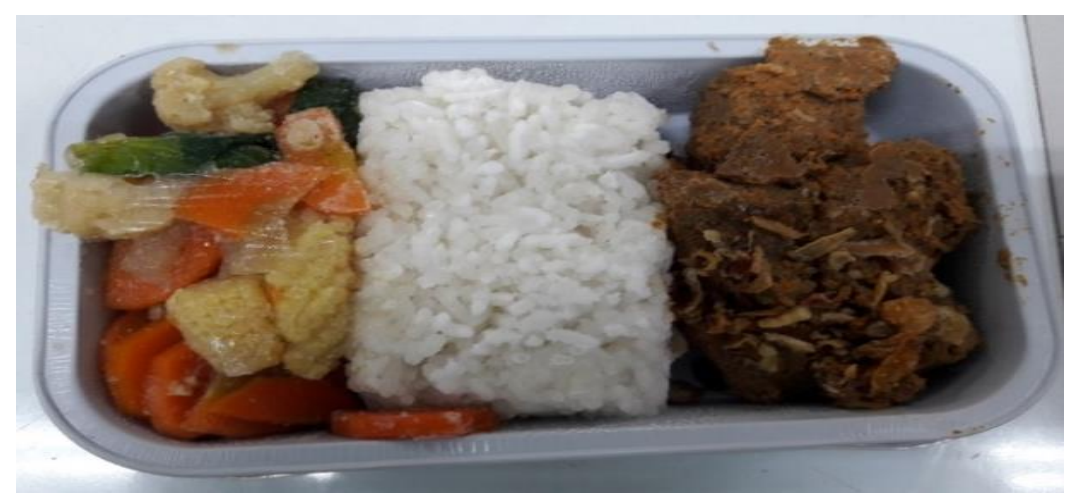

Gambar 2. Menu Moslem Meal yang telah di dishing 


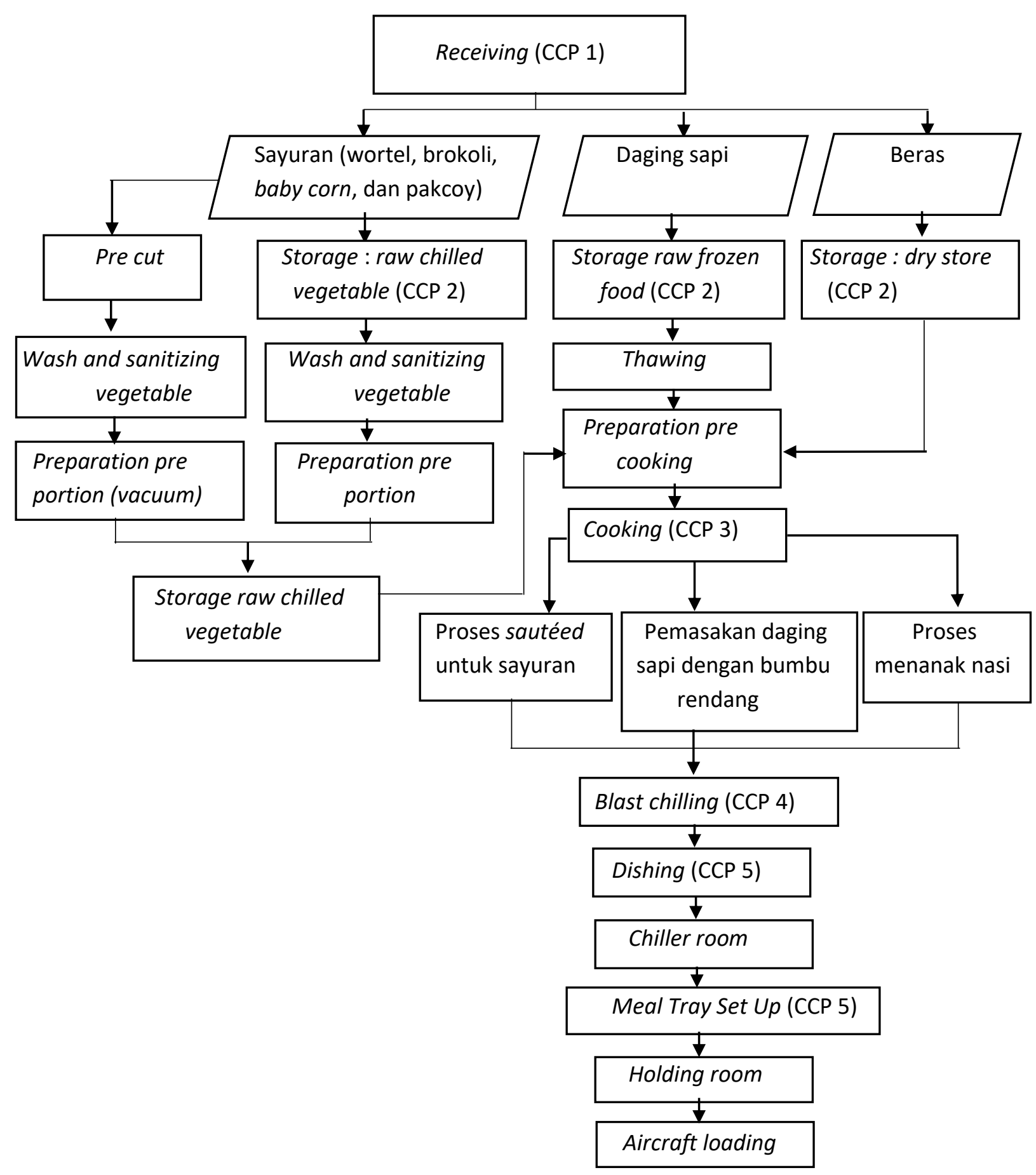

Gambar 1. Diagram alir proses pengolahan makanan menu moslem meal di PT. Aerofood Indonesia 


\section{Monitoring pada Penerimaan Bahan Baku (Receiving)}

Tahap pertama pada alur produksi adalah penerimaan bahan baku/receiving. PT. Aerofood Indonesia memesan bahan baku untuk membuat produknya kepada vendor/supplier ${ }^{9}$. Pada bagian ini dilakukan pengecekan oleh staf Quality Control (QC) dari segi kualitas dan kuantitas bahan baku yang akan diterima, dengan cara menimbang berat bahan baku, penyortiran bahan baku, pencatatan tanggal penerimaan dan kadaluarsa, pencatatan suhu bahan baku serta pemberian label disetiap bahan baku. Pengecekan dari segi kualitas berupa penyortiran bahan baku, sedangkan dari segi kuantitas berupa penimbangan berat dan jumlah bahan baku.

Selain itu staf $Q C$ juga mencatat setiap bahan baku yang datang seperti fruits and vegetables, dry goods, frozen foods, chill foods, ready to eat foods, serta mengisi formulir performance area receiving and store dan formulir report verifikasi CCP 1 (penerimaan bahan baku). PT. Aerofood Indonesia memiliki speck bahan baku yang ditetapkan pada manual book, sehingga apabila terdapat bahan baku yang dikirimkan oleh supplier tidak sesuai dengan speck yang dimiliki PT. Aerofood Indonesia maka bahan baku tersebut akan ditolak.

Monitoring bahan baku moslem meal pada bagian receiving sama seperti bahan baku lainnya, tidak ada pemisahan khusus antara bahan baku halal dan non halal. Bahan baku akan diterima jika sesuai dengan speck yang telah ditetapkan oleh PT. Aerofood Indonesia. Jika tidak sesuai maka QC yang bertugas dibagian receiving akan melakukan penyortiran bahan baku atau bahkan penolakan bahan baku. Spesifikasi bahan baku yang digunakan PT. Aerofood Indonesia mengacu pada SNI (Standar Nasional Indonesia) dan Codex Alimentarius.

\section{Monitoring pada Penyimpanan Bahan Baku (Storage)}

Bahan baku yang sudah sesuai dengan speck yang telah ditetapkan oleh PT. Aerofood Indonesia disimpan kedalam tempat penyimpanan/store. Tempat penyimpanan dibagi menjadi 2, yaitu dry store dan cold store. Bahan baku kering akan disimpan didalam dry store dan bahan baku yang memerlukan pendingan disimpan didalam cold store. Pada dry store, bahan kering akan dipisahkan sesuai dengan maskapai, maskapai Garuda Indonesia dan foreign airlines. Sedangkan pada cold store terdapat 7 chiller untuk menyimpan bahan baku dengan jenis dan suhu yang berbeda serta 1 chiller untuk bahan baku produk Jepang dan Korea. Pada area storage terdapat monitoring CCP 2, jika suhu permukaan produk diatas 8 으 maka produk harus dipindahkan ke chiller lainnya yang suhunya sesuai.

Sebelum bahan baku dimasukkan kedalam store, bahan akan diberikan label terlebih dahulu untuk memudahkan mengidentifikasi bahan dan memudahkan sistem FIFO (First In First Out). Sistem FIFO diberlakukan agar tidak ada bahan yang terlambat untuk dikeluarkan, serta mengurangi kemungkinan adanya bahan yang kadaluarsa. Tetapi pelabelan yang terdapat pada dry store di PT. Aerofood Indonesia masih kurang tepat. Masih ditemukan produk dengan label yang tidak sesuai. Jika label tidak sesuai, otomatis tanggal penerimaan dan tanggal kadaluarsa produk tersebut berbeda. Hal ini dikarenakan kelalaian staf storage yang tidak mengganti label secara teratur.

Monitoring bahan baku moslem meal pada bagian storage sama seperti bahan baku lainnya. Bahan baku dikelompokkan sesuai dengan jenisnya. Untuk bahan baku produk Jepang dan Korea disimpan di chiller yang berbeda, sehingga tidak bercampur dengan bahan baku lain. Selain itu staf QC mengisi formulir performance area receiving and store dan formulir report verifikasi CCP 2 (penyimpanan bahan baku).

Menurut salah satu staf QC Receiving and Storage produk Jepang dan Korea akan disimpan di chiller khusus bahan baku Jepang dan Korea, sehingga tidak akan bercampur dengan bahan baku lainnya. Setelah disimpan di store bahan baku tersebut akan dibawa ke hot kitchen dan diolah di ruangan non halal (personal communication, 23 Februari 2017). 


\section{Monitoring pada Persiapan Produk (Preparation)}

Bahan baku yang akan diolah di kitchen harus dilakukan persiapan terlebih dahulu. Persiapan yang dilakukan seperti persiapan pencucian sayur dan buah, pemotongan/pre cut, dan thawing. Pencucian sayur dan buah diawali dengan proses peeling, cutting, dan shredding. Proses peeling, cutting dan shredding dilakukan pada tahap persiapan produk guna mempermudah proses pencucian. Kemudian dilakukan perendaman dengan larutan klorin 50 - 100ppm. Perendaman dengan larutan klorin dilakukan agar bakteri yang menempel pada bahan baku dapat berkurang. Monitoring pada proses pencucian ini adalah dengan pengecekan apakah proses pencucian yang dilakukan sesuai dengan standar yang ditetapkan oleh PT. Aerofood Indonesia, serta melakukan pengecekan kadar klorin untuk pencucian sayur dan buah.

Pemotongan sayur dilakukan di ruang pre cut vegetables, sedangkan untuk pemotongan buah dilakukan di vegetables room. Untuk pemotongan ayam dan daging dilakukan di butcher, tetapi sebelum dilakukan pemotongan, bahan baku ayam dan daging dilakukan proses thawing setelah diambil dari freezer. Thawing dapat dilakukan dengan 2 cara, yaitu dengan cara thawing pada suhu ruangan dan thawing pada chiller. Thawing pada suhu ruangan harus dilakukan pemeriksaan setiap 6 jam sekali sejak proses thawing dimulai hingga selesai. Thawing pada chiller dilakukan pada suhu 0 - 10 ㄷ. Ruangan yang digunakan untuk thawing dipisah antara ruang thawing seafood dengan thawing daging dan ayam. Bahan daging dan ayam pun tidak diletakkan secara berdekatan, karena mencegah kontaminasi silang.

Untuk bahan baku kering (dry goods) tidak dilakukan proses persiapan pengolahan, tetapi langsung dilakukan proses pengolahan di ruang bumbu dan hot kitchen. Monitoring pada proses ini dengan melakukan pengecekan suhu ruangan, suhu chiller, suhu ruang thawing, dan suhu produk.

\section{Monitoring pada Proses Pengolahan}

Bahan baku yang sudah dilakukan pencucian dan pemotongan, selanjutnya diolah di kitchen. Proses pengolahan makanan main course dilakukan di hot kitchen dan dishing di hot dishing. Ruang hot kitchen digunakan untuk membuat hidangan panas yang berupa main course melalui proses pemasakan. Proses pemasakan yang dilakukan berupa penggorengan, pemanggangan, perebusan, steam, dan grill. Proses pengolahan special meal pada hot kitchen tidak ada pemisahan khusus dengan pengolahan makanan lainnya, tetapi pada bagian hot dishing tempat pengolahan special meal dipisahkan dengan pengolahan makanan lainnya agar mempermudah untuk pemorsian dan penataan makanan.

Untuk pembuatan appetizer dan dessert dilakukan di cold kitchen. Ruang cold kitchen digunakan untuk membuat hidangan dingin. Yang dimaksud hidangan dingin adalah makanan yang tidak memerlukan proses pemasakan dan proses pemanasan terlebih dahulu. Untuk pembuatan roti, cake, dan pudding dilakukan dibagian bakery and pastry.

Pada bagian produksi terdapat tempat pengolahan makanan khusus untuk produk non halal dan Japanese and Korean dishes, produk tersebut dimasak dan didishing ditempat yang sama. Sehingga tidak bercampur dengan produk halal. Dalam pengemasannya, produk tersebut diberikan label non halal, agar mempermudah mengidentifikasi makanan.

\section{Monitoring di Hot Kitchen}

Hot kitchen merupakan tempat untuk membuat hidangan panas yang berupa main course melalui proses pemasakan. Pada bagian hot kitchen, pengolahan makanan halal dan non halal dipisahkan. Untuk pengolahan makanan non halal memiliki tempat dan peralatannya sendiri. Sehingga untuk pembuatan menu moslem meal tidak akan bercampur dengan produk non halal.

Menurut salah satu staf QC hot kitchen menyatakan bahwa area hot kitchen terdapat 4 bagian, halal, first class, non halal dan Japan Korean dish. Dibagian first class mengolah makanan halal tetapi untuk penumpang first class, apabila dibagian non halal dan Japan Korean termasuk non halal tetapi Japan Korean itu bahan bakunya impor dari Jepang 
dan Korea sehingga area pengolahannya dipisah, dari mulai persiapan, pengolahan, pemasakan, dishing dilakukan ditempat yang sama, sehingga tidak bercampur dengan bahan lain (personal communication, 27 Februari 2017).

Pemasakan yang dilakukan di hot kitchen sesuai dengan permintaan disetiap maskapai. Sebagai contoh pada maskapai Garuda Indonesia Airlines untuk menu lunch pada menu moslem meal memiliki menu sebagai berikut: Steamed rice, beef rendang, capcay. Proses pemasakan nasi dilakukan dengan cara ditanak, beef rendang direbus, dan capcay direbus.

Hot kitchen termasuk CCP 3 (cooking) dan CCP 4 (blast chilling). Monitoring yang dilakukan pada hot kitchen adalah pengecekan suhu akhir pemasakan produk. Suhu akhir pemasakan produk berbeda setiap jenis makanan. Pemeriksaan CCP 3 dilakukan dengan cara memeriksa suhu inti makanan dengan menggunakan thermometer probe. Jika suhu akhir pemasakan tidak mencapai suhu yang telah ditetapkan maka makanan akan dimasak kembali hingga mencapai suhu yang telah ditetapkan.

Setelah makanan dimasak, makanan tersebut dimasukkan kedalam blast chiller. Didalam blast chiller, suhu makanan diturunkan hingga mencapai suhu $<10 \circ \mathrm{C}$ dalam waktu maksimal 4 jam. Jika suhu tersebut tidak tercapai dalam waktu 4 jam maka makanan akan dibuang. Blast chiller adalah alat pendingin makanan dengan menggunakan udara dingin dan kontak langsung dengan makanan secara cepat. Blast chiller digunakan untuk menurunkan suhu makanan hingga mencapai suhu $<10 \circ \mathrm{C}$ dalam waktu maksimal 4 jam. Setelah makanan dimasukkan kedalam blast chiller selama 4 jam, makanan dipindahkan kedalam chiller.

QC dibagian hot kitchen bertugas untuk mengontrol suhu ruangan, suhu chiller, melihat tanggal produksi makanan yang telah dibuat, memastikan tidak ada makanan yang terlalu lama didalam chiller, dan melakukan pengecekan kadar klorin di bak pencucian. Makanan yang telah dimasak tidak boleh lebih dari 3 hari didalam chiller. Selain itu monitoring juga dilakukan pada alat-alat yang digunakan untuk memasak dengan melakukan swab tes, memeriksa apakah terdapat serangga atau hewan di area hot kitchen, jika terdapat serangga maka dilaporkan kepada staf pest control. QC juga mengisi formulir performance hot kitchen, fruit and vegetable room, butcher, Japanese and Korean dishes, hot first class, dan formulir report verifikasi CCP 3 dan CCP 4.

\section{Monitoring di Hot Dishing}

Hot dishing merupakan tempat menata dan memorsikan hidangan yang telah dimasak di hot kitchen. Pada bagian hot dishing, makanan yang sudah dimasak dan dimasukkan kedalam chiller ditata/dishing sesuai dengan spesifikasi yang telah disepakati oleh PT. Aerofood Indonesia dengan maskapai penerbangan.

Menu special meal didishing ditempat yang berbeda dengan makanan regular lainnya. Sehingga dapat mempermudah penataan dan pemorsian makanan. Menu special meal dibuat apabila stock special meal sudah hampir habis/apabila ada pesanan. Sehingga pembuatan menu special meal lebih jarang dibandingkan dengan pembuatan menu regular lainnya. Stock special meal disimpan didalam lemari pendingin dengan diberi label sesuai dengan jenis special meal yang dibuat agar mempermudah membedakan makanan.

Menurut salah satu staf $\mathrm{QC}$ hot dishing dalam penataan menu special meal memiliki tempat khusus, tidak bergabung dengan menu regular lainnya, sehingga lebih mudah melihat pesanan dan menatanya. Menu special meal dibuat apabila stoknya habis dan jika terdapat pesanan dari maskapai. Menu moslem meal untuk Garuda Indonesia memiliki dua cycle, cycle berganti setiap bulan, menu cycle satu adalah nasi rendang dan capcay, menu cycle dua adalah nasi seafood dan brokoli. Setelah semua makanan di dishing sesuai buku menu kemudian diberi label sesuai dengan kode special meal (personal communication, 3 Maret 2017).

Monitoring pada hot dishing dilakukan dengan pengecekan suhu ruangan, suhu permukaan produk dan waktu portioning sesuai dengan CCP 5. Suhu ruangan 21 으, waktu portioning selama 45 menit, dan suhu 
permukaan produk maksimal $15 \circ \mathrm{C}$, jika tidak terpenuhi maka produk akan dibuang. Selain itu juga dengan pengecekan pada makanan apakah ada foreign object didalam makanan, kesegaran makanan, dan bau makanan. Pada area hot dishing, QC mencatat menu makanan setiap penerbangan di formulir food quality checklist dengan menimbang berat makanan dan suhu permukaan produk, mengisi formulir performance hot dishing, dan formulir report verifikasi CCP 5.

Setelah didishing, makanan dimasukkan kedalam chiller. Makanan yang telah didishing tidak boleh berada di chiller selama lebih dari 3 hari, jika ada yang lebih dari 3 hari maka harus segera dibuang atau dilaporkan kepada pihak terkait di area tersebut. Karena makanan yang telah didishing tidak hanya satu jenis makanan, tetapi sudah bercampur dengan makanan lainnya, sehingga daya tahan simpan makanan tersebut tidak bertahan lama.

\section{Monitoring di Cold Kitchen}

Cold kitchen merupakan tempat membuat hidangan dingin. Hidangan dingin adalah makanan yang tidak membutuhkan proses pemasakan dan proses pemanasan kembali didalam pesawat. Menu yang didishing di cold kitchen adalah menu untuk appetizer, dessert, sandwich dan makanan lainnya yang berbahan dasar buah. Pada pembuatan appetizer, dessert, dan sandwich untuk moslem meal tidak berbeda dengan pembuatan menu regular lainnya.

Monitoring pada cold kitchen dilakukan pengecekan suhu ruangan, suhu permukaan produk, dan suhu portioning sesuai dengan CCP 5. Suhu ruangan maksimal $21^{\circ} \mathrm{C}$, suhu permukaan produk maksimal $15 \circ \mathrm{C}$, dan waktu portioning maksimal selama 45 menit, jika tidak terpenuhi maka produk akan dibuang. Selain itu juga dengan pengecekan pada makanan apakah ada foreign object didalam makanan, kesegaran makanan, menimbang berat produk sesuai dengan standar atau tidak dan bau makanan. Pada area cold kitchen, QC mencatat menu makanan setiap penerbangan di formulir food quality checklist dengan menimbang berat makanan dan suhu permukaan produk, mengisi formulir performance cold kitchen, dan formulir report verifikasi CCP 5.

Makanan yang telah didishing akan dimasukkan kedalam chiller. Makanan yang telah didishing tidak boleh berada di chiller selama lebih dari 3 hari, jika ada yang lebih dari 3 hari maka harus segera dibuang atau dilaporkan kepada pihak terkait di area tersebut.

\section{Monitoring di Pastry and Bakery}

Pastry and bakery merupakan tempat untuk membuat roti, cake, dan cokelat. Didalam pastry and bakery terdapat pastry room, bakery room, chocolate room, dan croissant room. Pada pembuatan produk roti untuk moslem meal tidak berbeda dengan pembuatan roti regular lainnya.

Monitoring pada pastry and bakery dilakukan dengan pengecekan suhu ruangan, suhu permukaan produk dan waktu portioning sesuai dengan CCP 5 . Suhu ruangan maksimal $21 \mathrm{C}$, suhu permukaan produk maksimal $15^{\circ} \mathrm{C}$, dan waktu portioning maksimal selama 45 menit, jika tidak terpenuhi maka produk akan dibuang. Selain itu juga dengan pengecekan pada makanan apakah ada foreign object didalam makanan, kesegaran makanan, menimbang berat produk sesuai dengan standar atau tidak dan bau makanan. Pada area bakery and pastry, QC mencatat menu makanan setiap penerbangan di formulir food quality checklist dengan menimbang berat makanan dan suhu permukaan produk, mengisi formulir performance bakery and pastry, dan formulir report verifikasi CCP 5 .

\section{Monitoring di Meal Tray Set Up (MTSU)}

MTSU merupakan tahap terakhir dalam proses pengolahan makanan. MTSU merupakan tempat untuk menata seluruh makanan dari appetizer, main course, dessert, roti, minuman dan equipment untuk setiap penerbangan kedalam tray. Setelah makanan dimasukan kedalam tray, kemudian tray dimasukan kedalam troli yang selanjutnya troli dimasukkan ke dalam holding room minimal selama 3 jam sebelum diberangkatkan ke dalam pesawat agar suhu makanan tetap terjaga. Holding room adalah tempat 
pendinginan makanan terakhir sebelum didistribusikan kedalam pesawat.

MTSU dibagi menjadi 2 bagian, yaitu domestic area dan foreign area serta dilengkapi dengan holding room. Makanan diatur sesuai dengan Airline Meal Order Set (AMOS). AMOS merupakan panduan dan informasi mengenai menu makanan, jumlah pesanan dari setiap maskapai penerbangan.

Monitoring pada MTSU dilakukan dengan pengecekan suhu ruangan, suhu permukaan produk dan waktu portioning sesuai dengan CCP 5 . Suhu ruangan maksimal 21 으, suhu permukaan produk maksimal 15 으 dan waktu portioning maksimal selama 45 menit, jika tidak terpenuhi maka produk akan dibuang. Selain itu dilakukan pengecekan kesegaran makanan dan bau makanan. Monitoring dimulai dengan melakukan pengecekan makanan apakah sesuai dengan AMOS atau tidak, makanan dicek secara random untuk memeriksa suhu dan bau makanan, apakah sesuai dengan standar yang telah ditentukan oleh PT. Aerofood Indonesia. Pada area MTSU, QC melakukan pengecekan troli yang sudah diisi dengan makanan dengan menggunakan formulir meal prepare control, mengisi formulir performance meal tray set up, dan formulir report verifikasi CCP 5.

Tabel 1. Jenis-jenis special meal

\begin{tabular}{|c|c|c|c|}
\hline No & Meal & $\begin{array}{l}\text { IATA } \\
\text { Code }\end{array}$ & Description \\
\hline \multicolumn{4}{|c|}{ Vegetarian Meal } \\
\hline 1. & Vegetarian Vegan Meal & VGML & $\begin{array}{l}\text { These vegetarian meals strictly exclude meat or animal } \\
\text { product, including honey, eggs or milk (products). }\end{array}$ \\
\hline 2. & $\begin{array}{l}\text { Vegetarian Lacto Ovo } \\
\text { Meal }\end{array}$ & VLML & $\begin{array}{l}\text { This menu excludes meat, fish and poultry and products } \\
\text { which features the ingredients. However, include other } \\
\text { animal products such as eggs and milk (products). Soya } \\
\text { products and other meat substitutes are used. }\end{array}$ \\
\hline 3. & Asian Vegetarian Meal & AVML & $\begin{array}{l}\text { These meals exclude meat, fish, poultry and products } \\
\text { which feature these ingredients. However, include other } \\
\text { animal products such as milk (products). This menu has an } \\
\text { Indian accent and is prepared with oriental herbs and } \\
\text { spices. }\end{array}$ \\
\hline 4. & Fruit Plate Meal & FPML & $\begin{array}{l}\text { The main ingredients of this vegetarian menu are fruit. } \\
\text { However, for extra variety, it may also include ingredients } \\
\text { such as vegetables, nuts and cheese. }\end{array}$ \\
\hline \multicolumn{4}{|c|}{ Medical Health-care } \\
\hline 5. & Low Sodium Meal & LSML & $\begin{array}{l}\text { Salty products are excluded and no salt is added during } \\
\text { preparation to prevent high blood preassure. }\end{array}$ \\
\hline 6. & $\begin{array}{l}\text { Low Fat/Low } \\
\text { Cholesterol Meal }\end{array}$ & LFML & $\begin{array}{l}\text { Featuring limited cholesterol and a high percentage of } \\
\text { polyunsaturated fats, the high-fibre meals are suitable for } \\
\text { a cholesterol-reducing diet. }\end{array}$ \\
\hline 7. & Low Protein Meal & LPML & $\begin{array}{l}\text { Restrict foods containing high biological value protein } \\
\text { (meat, fish, eggs, and dairy products); avoid highly salted } \\
\text { foods; do not use salt in food preparation. }\end{array}$ \\
\hline 8. & Low Calorie Meal & LCML & $\begin{array}{l}\text { This menu features increased complex carbohydrates with } \\
\text { high fibre foods used wherever possible: low in fat with } \\
\text { approximately } 1200 \text { calories in a 24-hour period. }\end{array}$ \\
\hline 9. & Diabetic Meal & DBML & $\begin{array}{l}\text { Proteins, fats and carbohydrates must be equal. Meals } \\
\text { feature an increased proportion of complex carbohydrates } \\
\text { and fibre. A small amount of fat is used, a large proportion } \\
\text { of which is polyunsaturated. Products containing sugar }\end{array}$ \\
\hline
\end{tabular}




\begin{tabular}{|c|c|c|}
\hline & & feature to a limited extent. \\
\hline Peanut Free Meal & PFML & Products exclude any trace of peanut. \\
\hline Gluten Free Meal & GFML & $\begin{array}{l}\text { Feature gluten free products. Products containing wheat, } \\
\text { rye, oats or barley are therefore not included. }\end{array}$ \\
\hline 12. Non Lactose Meal & NLML & $\begin{array}{l}\text { This menu excludes the use of cow's milk protein or } \\
\text { lactose. }\end{array}$ \\
\hline 13. Bland/Soft Meal & BLML & $\begin{array}{l}\text { Light, easily digestible meal for stomach/intestinal } \\
\text { problems. }\end{array}$ \\
\hline 14. High Fibre Meal & HFML & $\begin{array}{l}\text { High nutritious products with water soluble and water } \\
\text { insoluble fibre. }\end{array}$ \\
\hline 15. Low Purine Meal & PRML & $\begin{array}{l}\text { Meal without offal products. Prepared to decrease } \\
\text { elevated blood and urinary acid levels. }\end{array}$ \\
\hline 16. Seafood Meal & SFML & $\begin{array}{l}\text { Fish and/or seafood prepared according to local } \\
\text { specifications. }\end{array}$ \\
\hline Religious Meal & & \\
\hline 17. Kosher Meal & KSML & $\begin{array}{l}\text { All Kosher food is prepared under strict rabbinical } \\
\text { supervision and supplied by authorized suppliers. Meals } \\
\text { are sealed to guarantee purity. }\end{array}$ \\
\hline 18. Moslem Meal & MOML & $\begin{array}{l}\text { Meals are prepared instrict accordance with the Sharia } \\
\text { and exclude pork and alcohol. }\end{array}$ \\
\hline 19. Hindu Meal & HNML & $\begin{array}{l}\text { These meals are prepared strictly according to Hindu } \\
\text { directives. Exclude all meat products from the cow. Hindu } \\
\text { meals are usually vegetarian. }\end{array}$ \\
\hline Children/Infant Me & & \\
\hline 20. Baby Meal & BBML & $\begin{array}{l}\text { Selection of pots of pureed foods for babies between } 10 \\
\text { weeks and two years. }\end{array}$ \\
\hline 21. Children Meal & CHML & $\begin{array}{l}\text { Serve a special fun box for children aged between two and } \\
\text { nine years. }\end{array}$ \\
\hline
\end{tabular}

(Sumber: IFCA, 2004)

Tabel 2. Menu Moslem Meal

\begin{tabular}{lll}
\hline \multicolumn{1}{c}{ Hot Lunch } & \multicolumn{1}{c}{ Cycle 1 } & \multicolumn{1}{c}{ Cycle 2 } \\
\hline Appetizer & -Marinated king prawn & -Grilled chicken breast with orange \\
& -Japanese cup with thousand island & sauce \\
& -Lemon wedge & -Tomato wedge \\
& -Lettuce, frisee, red coral & -Orange segment \\
& -Parsley leaf & -Lettuce, frisee, red coral \\
\hline Main Course & -Steamed rice & -Steamed rice \\
& -Beef Rendang & -Seafood chilly sauce \\
& -Capcay & -Sauteed broccoli and carrot \\
\hline Salad & -Gado-gado peanut sauce & -Asinan bogor \\
\hline Dessert & -Nagasari with coconut sauce & -Palu butung with strawberry sauce \\
\hline TSU & -Kerupuk udang & -Kerupuk udang \\
& -Sambal in bag & -Sambal in bag \\
\hline
\end{tabular}

(Sumber: PT. Aerofood Indonesia, 2017) 
Tabel 3. Jenis dan suhu cold store

\begin{tabular}{|c|c|}
\hline Bahan Baku & Suhu \\
\hline Sayuran & $3-9$ 으 \\
\hline Buah & $3-9 \circ \mathrm{C}$ \\
\hline Bumbu dan sayuran yang sudah dipotong & $3-9 \circ \mathrm{C}$ \\
\hline Barang siap pakai & $0-5$ 으 \\
\hline Keju/jus & $0-5 \circ \mathrm{C}$ \\
\hline Telur ayam & $3-9 \circ \mathrm{C}$ \\
\hline Frozen food & $(-18)-(-30) \stackrel{\circ}{C}$ \\
\hline Japanese dan Korean & $(-18)-(-30) \stackrel{\circ}{ } \mathrm{C}$ \\
\hline
\end{tabular}

Selain monitoring pada makanan, dibagian MTSU juga dilakukan monitoring pada troli yang digunakan, kebersihan equipment, dan kebersihan high lift truck yang digunakan untuk mengantarkan makanan ke pesawat. Monitoring pada saat pendistribusian makanan ke pesawat harus ditekankan agar suhu makanan tetap sesuai standard dan tidak ada tanda-tanda kerusakan pada makanan.

\section{KESIMPULAN}

Monitoring kualitas makanan di PT. Aerofood Indonesia adalah tugas semua karyawan yang terlibat dalam proses produksi, tetapi yang bertanggungjawab adalah staff Quality Control dengan dibantu oleh production control disetiap area produksi. Monitoring pada menu moslem meal dilakukan dari penerimaan bahan baku, penyimpanan bahan baku, persiapan bahan baku, pengolahan produk, portioning, meal tray set up hingga pendistribusian ke dalam pesawat. Proses pengolahan makanan produk halal dengan produk non halal dipisahkan tempat dan equipmentnya dari area hot kitchen hingga didishing. Monitoring disetiap area difokuskan pada critical control point yang sudah ditetapkan oleh PT. Aerofood Indonesia.

\section{ACKNOWLEDGEMENT}

Terima kasih kepada staf Quality Control PT. Aerofood Indonesia yang telah membantu selama penelitian berlangsung. Terima kasih dan penghargaan juga diberikan penulis kepada seluruh staf pengajar program studi ilmu gizi Universitas Airlangga atas bimbingan yang telah diberikan.

\section{REFERENSI}

1. Mulia, R. M. Kesehatan Lingkungan. Yogyakarta: Graha IImu. 2005.

2. Wicaksono, Y. S. Analisis Kualitas Penerbangan (Airqual) di Indonesia: Hubungan terhadap Kepuasan Pelanggan, Repurchase Intention, serta Word of Mouth. Tesis. Fakultas Ekonomi. Universitas Indonesia. 2012.

3. Rachmayanti. Kajian Manajemen Teknologi Produksi Flight Catering di ACS Jakarta. Jurnal IImial Kesatuan 2001;1(3).

4. Eriteria, F. Gambaran Penerapan Food Safety pada Pengolahan Makanan untuk Kru Pesawat di Aerofood ACS Tahun 2012. Skripsi. FKM UI. 2012.

5. PT. Aerofood Indonesia. Guideline Book. 2017.

6. Thaheer, Hermawan. Sistem Manajemen HACCP (Hazard Analysis Critical Control Points). Jakarta: Bumi Aksara. 2005.

7. Hidayat, H. H. dan Djatna, T. A Value Stream Mapping for Supporting Set Aside Halal Food on International InFlight Meal Services. Journal of Halal Research 2016;1(1): 6-9.

8. Yunita, M. Analisis Kuantitatif Mikrobiologi pada Makanan Penerbangan (Aerofood ACS) Garuda Indonesia Berdasarkan TPC (Total Plate Count) degan Metode pour Plate. Jurnal Keteknikan Pertania Tropis dan Biosistem 2015; 3(3). 
9. Muifitdah, I. dan Sutianingsih, A. Penyelenggaraan Pembelian (Purchasing) Bahan Baku PT. Aerofood Aerowisata Catering Service (PT.
Aerofood ACS) Surabaya. E-Journal Boga 2013;2(3):69-76.

10. Jones, P. Flight Catering. International Flight Catering Association. London: Elsevier Butterworth-Heinemann. 2004. 